\title{
Ikhlas Dan Spiritualitas Kerja Terhadap Profesionalisme Guru Pada Guru Pondok Pesantren
}

\author{
Gina, Mubarak, Shanty Komalasari \\ Universitas Islam Negeri Antasari Banjarmasin
}

\begin{abstract}
Abstrack
Teacher professionalism is a person who has the authority, responsibility to guide and foster students at school or outside of school with special expertise in the field of teacher training. Thus teachers are able to carry out their duties and functions to the maximum capacity. Teachers must also have the competence to become professional teachers. In principle, being a professional teacher cannot be separated from the four basic elements of teacher competence, namely competence in the fields of pedagogy, social competence, personality competence, and professional competence. Therefore, the researcher wanted to conduct research on the influence of sincerity and work spirituality on teacher professionalism at the Darul Hijrah Putri Martapura Islamic Boarding School.

This research is a field research (field research) with a quantitative approach. The population in this study were 53 teachers of the Darul Hijrah Putri Martapura Islamic boarding school. Based on this study, the results obtained: 1) There is a significant influence between sincerity and spirituality of work on the professionalism of teachers in the Darul Hijrah Putri Martapura Islamic boarding school with a significance level of $0.004(p<0.05)$ and together it makes an effective contribution of $19,9 \%$. 2) There is a significant influence between sincerity on the professionalism of teachers at the Darul Hijrah Putri Martapura Islamic boarding school with a significance level of $0.023(p<0.05)$ and an effective contribution of $19.1 \%$. 3) There is a significant influence between work spirituality on teacher professionalism at Darul Hijrah Putri Martapura Islamic boarding school with a significance level of $0.002(p<0.05)$ and an effectivecontribution of $16.8 \%$.
\end{abstract}

Keywords: Ikhlas; Darul Hijrah Putri Martapura Islamic Boarding School; Work Spirituality; Teacher Professionalism.

\begin{abstract}
Abstrak
Profesionalisme guru adalah orang yang memiliki kewenangan, tanggung jawab untuk membimbing serta membina peserta didik di sekolah atau di luar sekolah dengan keahlian khusus dalam bidang keguruan. Dengan demikian guru mampu melakukan tugas dan fungsinya dengan kemampuan maksimal. Guru juga harus memiliki kompetensi untuk menjadi guru profesional. Pada prinsipnya, menjadi seorang guru yang profesional tidak akan lepas dari empat elemen dasar kompetensi guru, yaitu kompetensi dalam bidang pedagogik, kompetensi sosial, kompetensi kepribadian, dan kompetensi profesional. Maka dari itu, peneliti hendak melakukan penelitian mengenai Pengaruh Ikhlas dan Spiritualitas Kerja Terhadap Profesionalisme Guru di Pondok Pesantren Darul Hijrah Putri Martapura.
\end{abstract}


Penelitian ini merupakan penelitian lapangan (field research) dengan pendekatan kuantitatif. Populasi dalam penelitian ini adalah guru pondok pesantren Darul Hijrah Putri Martapura yang berjumlah 53 orang. Berdasarkan penelitian ini, maka didapatkan hasil: 1) Terdapat pengaruh yang signifikan antara ikhlas dan spiritualitas kerja terhadap profesionalisme guru di pondok pesantren Darul Hijrah Putri Martapura dengan taraf signifikansi 0,004 ( $p<0,05)$ dan secara bersama-sama memberi sumbangan efektif sebesar 19,9\%. 2) Terdapat pengaruh yang signifikan antara ikhlas terhadap profesionalisme guru di pondok pesantren Darul Hijrah Putri Martapura dengan taraf signifikansi 0,023 ( $p<0,05)$ dan memberi sumbangan efektif sebesar 19,1 \%. 3) Terdapat pengaruh yang signifikan antara spiritualitas kerja terhadap profesionalisme guru di pondok pesantren Darul Hijrah Putri Martapura dengan taraf signifikansi 0,002 $(\mathrm{p}<0,05)$ dan memberi sumbangan efektif sebesar $16,8 \%$.

Kata Kunci: Ikhlas; Pondok Pesantren Darul Hijrah Putri Martapura; Spiritualitas Kerja; Profesionalisme Guru.

Pembelajaran Islam pada dasarnya bermaksud untuk membentuk individu muslim dengan utuh, meningkatkan segala kemampuan manusia baik yang berupa jasmani ataupun rohani. Penerapan pendidikan Islam bisa dijalankan dalam bermacam wujud semacam pesantren, madrasah, serta model pendidikan yang lain. Pesantren ialah sebagian dari beberapa jenis pembelajaran Islam Indonesia yang bercirikan tradisional atau lama sebagai wadah menghayati serta mengamalkan dalam keseharian (tafaqquh fiddin) ialah mendalami serta menjalankan kehidupan bermasyarakat dan pentingnya akhlak dengan berpedoman pada pembelajaran Islam (Widyaningsih, 2016). Dalam menentukan keberhasilan pembelajaran di pesantren, guru merupakan faktor sumber energi yang sangat penting, sebab peserta didik dan guru adalah faktor manusiawi yang sangat dekat dalam upaya pembelajaran di pesantren. Tanpa dorongan guru maka tidak akan tumbuh keahlian serta kemampuan peserta didik secara maksimal. Dalam kaitannya peserta didik diperhatikan oleh guru secara khusus. Tugas guru tidak cuma mengurus, mengajar, tetapi pula mendidik dan membimbing, serta membina karakter peserta didik guna mempersiapkan serta meningkatkan SDM (Sumber Daya Manusia) (Sriani, Srigati, Mushofiah, \& Imam Maliki, 2016). Untuk tetap mewujudkan serta meningkatkan mutu profesionalnya perlu diwujudkan kerja profesional guru seperti ditunjang dengan jiwa profesionalisme yaitu sikap mental dalam wujud komitmen anggota suatu profesi. 
Profesionalisme adalah bahwa anggota berkomitmen untuk meningkatkan keahlian serta meningkatkan strategi-strategi yang diterapkannya dalam melaksanakan pekerjaan yang cocok dengan profesi mereka, secara profesional dan terus menerus (Manurung \& Harni, 2008). Profesionalisme ialah motivasi intrinsik (dari dalam diri) seorang guru sebagai pendorong untuk meningkatkan taraf profesionalnya. Guru dengan tingkat profesionalisme tinggi akan menunjukkan tekad dan sikap mental terhadap pelaksanaan serta peningkatan mutu profesional lewat bermacam metode serta strategi dalam melayani kebutuhan pembelajaran peserta didik. Semakin besar derajat profesi yang disandangnya maka semakin tinggi tingkatan pendidikan yang harus terwujud oleh seorang. (Ulfah, Yuliejantiningsih, \& Soegeng, 2017). Dengan perkataan lain besar kecilnya pengakuan profesionalisme sangat bergantung pada kemampuan serta tingkatan pendidikan yang dilewatinya. Profesionalisme merupakan suatu pencapaian yang membutuhkan pemeliharaan serta pengembangan yang dilaksanakan terus menerus serta tidak bisa berakhir pada suatu titik yang dikira telah dikatakan bisa sukses (Wahyuning, 2016). Guru yang profesional tidak cuma pakar, disiplin serta bertanggung jawab, namun juga wajib dilandasi oleh kenyataan bahwa guru yang menjalankan tugasnya suatu perintah seperti beribadah kepada Allah. Oleh karena itu, dalam mengembangkan karirnya, guru harus dilandasi keimanan kepada Tuhan, dedikasinya serta keikhlasannya. Selain menjadi panutan, guru juga harus memiliki karakter yang baik, sehingga menjadi acuan dan perilaku terhadap peserta didik (Faturahman \& Suryana, 2012). Sebagaimana Allah berfirman dalam Q.S. Hud/11: 93:

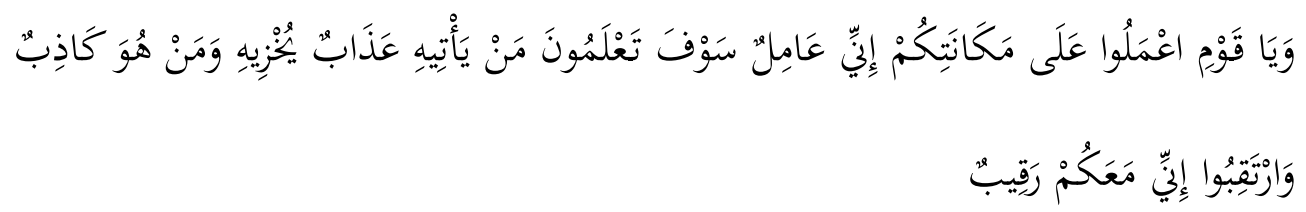

Artinya: "Dan Dia berkata: umatku, berbuatlah menurut kemampuanmu. Sesungguhnya akupun berbuat (pula). Kelak kamu akan mengetahui siapa yang akan ditimpa azab yang menghinakannya dan siapa yang berdusta.Dan tunggulah azab (Tuhan), sungguh, aku menunggu bersamamu".

Profesionalisme merupakan suatu pencapaian yang membutuhkan pemeliharaan serta pengembangan yang dilaksanakan terus menerus serta tidak bisa berakhir pada suatu titik 
yang dikira telah dikatakan bisa sukses, akan tetapi pada hasil wawancara yang dilakukan peneliti di pondok pesantren Darul Hijrah Putri Martapura masih terdapat hambatan untuk meningkatkan profesionalisme guru baik dalam lingkup pendidikan ataupun diluar pendidikan. Problematika itu sendiri diakibatkan oleh aspek internal serta eksternal guru antara lain heterogenitas peserta didik dengan macam kemampuannya yang mana guru harus bisa mengenali kondisi tiap peserta didik, supaya bisa melaksanakan tugas mendidiknya dengan baik, sebab menguasai pertumbuhan peserta didik merupakan kompetensi yang dipunyai guru. Tidak hanya itu kondisi kelas serta area lembaga sangat mempengaruhi untuk guru yang setelah itu berakibat pula pada kompetensi yang dipunyai oleh tiap guru yang dikelompokkan sebagai problem eksternal yaitu problem yang berasal dari luar diri guru itu sendiri. Perihal ini bisa dilihat dari guru yang mengajar serta mendidik peserta didik secara profesional dan ikhlas dalam membagikan ilmu kepada anak didiknya serta menyertakan nilai spiritual dalam bekerja dan menciptakan suasana pendidikan yang efisien supaya menciptakan output yang siap mengalami tantangan zaman.

Ikhlas berasal dari bahasa Arab yang maksudnya murni, tidak tercampur, bersih dan jernih. Kata ikhlas bisa disamakan dengan sincere (bahasa Latin sincerus: pure) yang berarti suasana atau hal nyata yang mengungkapkan hati nuraninya yang sangat dalam. Dalam Kamus Besar Bahasa Indonesia (KBBI) ikhlas maksudnya merupakan ketersediaan, kejujuran dan kesucian hati (Depdikbud, 2005). Menurut Qalami dalam Chizanah, ikhlas dimaksud sebagai hasrat yang murni hanya berharap mendapat restu Tuhan ketika melaksanakan suatu tindakan, dan bukan menyekutukan Tuhan dengan yang lain. Ikhlas bagaikan wujud sikap membantu didasari hasrat baik, tidak mementingkan diri sendiri, dan keberkahan bagi dirinya (Chizanah, 2011). Menurut Bugi, ikhlas berarti bersih dari seluruh kotoran dan menjadikannya bersih serta tidak kotor. Sebaliknya menurut Imam al-Ghazali ikhlas merupakan melaksanakan segala sesuatu dengan diiringi hasrat untuk mendekatkan diri kepada Allah SWT dari seluruh wujud ketidak murnian selain mendekatkan diri kepada Allah. (Daud, 2017).

Spiritualitas berasal dari bahasa latin spiritus. Kata dari bahasa latin tersebut memiliki arti napas. Kata spiritus mempunyai arti yang sama dengan kata hikmat, kebijaksanaan, kecerdasan, keahlian untuk berpikir, dan vitalitas jiwa ataupun nonfisik yang lain. Spiritualitas 
sangat praktis, yaitu untuk menciptakan arti serta tujuan dalam dunia yang tampaknya tidak sempurna, kemudian memakai pengetahuan yang telah dipelajari untuk menghasilkan kehidupan yang sehat, senang, sejahtera serta memuaskan untuk diri kita sendiri serta orang lain (Wulandari, 2017). Menurut Ashmos dan Duchon, spiritualitas bukanlah hal baru dalam pengalaman manusia. Dalam semua tradisi agama utama, kehidupan kontemplatif telah dibudidayakan sampai batas tertentu, di mana pencarian arti dan tujuan menjadi pertimbangan utama, dan harmoni dengan orang lain dianggap bermakna. Dalam kehidupan individu, spiritualitas semacam itu normal tumbuh walaupun wajib berhadapan dengan aliran nilai-nilai lain yang cenderung merangsang perolehan materi. Namun, dalam dunia kerja, orang yang menghadapi spiritualitas sering kali berbenturan dengan batasan-batasan manajemen sebagai alat non-manusia untuk mencapai tujuan akhir material dan menjalankan fungsi kontrol (Yogatama, 2015). Menurut Pierre spiritualitas dapat menolong seorang dalam menciptakan makna dalam hidup, mendorong untuk berpikir dan melakukan sesuatu, mendorong keharmonisan dengan Tuhan, alam dan masyarakat, termasuk menemukan kedamaian batin, spiritualitas bisa memberikan semangat, melepaskan belenggu kesulitan dan juga memberikan cara untuk bertransformasi menuju diri yang lebih bermakna (Syamsuddin, 2012). Giacalone dan Jurkiewicz mendefinisikan spiritualitas sebagai kerangka nilai-nilai organisasi. Budaya ini diwujudkan dalam budaya yang mempromosikan pengalaman pribadi melalui proses kerja, dan meningkatkan rasa ketertarikan dengan orang lain dengan metode yang memberikan rasa kelengkapan dan kegembiraan (Alexandri \& Fithriya Zahra, 2017).Milliman, Czaplewski, dan Ferguson juga mengemukakan bahwa spiritualitas dalam bekerja adalah mengungkapkan keinginan untuk menemukan arti dan tujuan dalam hidup, serta merupakan proses mewujudkan rangkaian nilai-nilai individu yang dimiliki seseorang (Nurtjahjanti, 2010) . Sedangkan menurut Kinjerski dan Skrypnek mendefinisikan pengalaman individu menjadi bersemangat dan mendapatkan energi dari pekerjaan, mendapatkan arti dan tujuan di tempat kerja , dan pengalaman di mana orang dapat mengekspresikan diri mereka di tempat kerja serta terhubung dengan orang-orang yang bekerja (Mengko \& Vesty Like Sambeka, 2018). 


\section{Metode Penelitian}

Jenis penelitian yang digunakan adalah penelitian kuantitatif dengan metode penelitian lapangan atau field research. Subjek pada penelitian ini adalah guru pondok pesantren Darul Hijrah Putri Martapura yaitu 53 orang. Teknik dalam pengambilan sampel pada penelitian ini adalah teknik nonprobability sampling, teknik pengambilan sampel yang tidak memberikan peluang yang sama bagi setiap elemen (anggota) untuk dipilih (Sugiyono, 2010) Sampel dalam penelitian ini yaitu 50 subjek dengan tingkat kepercayaan 99\% (Endang Mulyatiningsih, 2011). Objek pada penelitian ini yaitu ikhlas dan spiritualitas kerja sebagai variabel bebas serta profesionalisme guru sebagai variabel terikat.

Pengumpulan data dalam penelitian ini menggunakan 3 skala psikologi yaitu skala ikhlas, spiritualitas kerja, dan profesionalisme guru. Skala ikhlas disusun berdasarkan aspek yang dikemukakan oleh Chizanah dan Hadjam yang menggambarkan ikhlas seseorang seperti motif transendental, pengendalian emosi, tidak adanya superiority feeling, dan konsepsi sebagai hamba Tuhan (Chizanah \& Hadjam, 2013). Skala spiritualitas kerja dalam penelitian ini menggunakan skala yang disusun oleh Milliman, Czaplewski, dan Ferguson berkaitan pekerjaan yang bermakna (meaningful work), rasa komunitas (sense of community), dan penegakan nilai dalam organisasi (alignment with organizational value). Dan skala profesionalisme guru pada penelitian ini menggunakan gambaran profesionalisme ditinjau melalui aspek yang dikemukakan oleh Mulyasa yaitu kompetensi pedagogik, kompetensi kepribadian, kompetensi sosial dan kompetensi profesional. Selain itu pada penelitian ini juga menggunakan dokumentasi, wawancara dan observasi sebagai data pendukung.

Analisa data pada penelitian ini menggunakan teknik analisis regresi berganda. Analisis regresi berganda dilakukan untuk penelitian yang memiliki satu variabel terikat dan lebih dari satu variabel bebas (Sujarweni, 2019). Sebelum melakukan uji analisis maka dilakukan uji asumsi dasar yaitu uji normalitas dan uji linieritas serta uji asumsi klasik yaitu uji multikolinieritas dan uji heterokedastisitas. Proses analisis dibantu dengan menggunakan program komputer Statictical Packages for Social Sciense (SPSS) Release 20.0 for windows. 


\section{Hasil}

\section{Uji Asumsi Dasar}

Hasil uji normalitas pada variabel ikhlas, spiritualitas kerja, dan profesionalisme guru menunjukkan nilai signifikansi kolmogorov-smirnov sebesar nilai sig. $(p>0,05)$ untuk variabel ikhlas $0,197 \geq 0,05$, variabel spiritualitas kerja $0,161 \geq 0,05$, dan variabel profesionalisme guru 0,191 $\geq 0,05$. Hal ini menunjukkan bahwa data ikhlas, spiritualitas kerja, dan profesionalisme guru pada penelitian ini memiliki data yang berdistribusi normal. Hasil uji linieritas untuk variabel ikhlas terhadap profesionalisme guru menunjukkan nilai signifikansi $0,011(\mathrm{p}<0,05)$. Hal ini menunjukkan bahwa perubahan variabel bebas ikhlas akan cenderung diikuti oleh perubahan variabel terikat profesionalisme guru. Sedangkan uji linieritas untuk variabel spiritualitas kerja terhadap profesionalisme guru 0,006 ( $<<0,05)$. Hal ini menunjukkan bahwa perubahan variabel bebas spiritualitas kerja akan cenderung diikuti oleh perubahan variabel terikat profesionalisme guru.

\section{Uji Asumsi Klasik}

Hasil uji multikolinieritas pada kedua variabel bebas yaitu ikhlas dan spiritualitas kerja memiliki VIF masih diantara 1-10 yaitu sebesar VIF=1,147. Artinya antara variabel bebas tidak terjadi multikolinieritas atau kemiripan, sehingga memenuhi syarat untuk dianalisis regresi. Sehingga tidak bias dalam proses pengambilan keputusan mengenai pengaruh pada uji parsial masing-masing variabel bebas terhadap variabel terikat. Selanjutnya hasil uji heterokedastisitas pada kedua variabel bebas yaitu ikhlas dan spiritualitas kerja memiliki nilai signifikansi ( $\mathrm{p}>$ 0,05). Variabel ikhlas $(0,169 \geq 0,05)$ dan spiritualitas kerja $(0,148 \geq 0,05)$. Artinya tidak ada ketidaksamaan varian dari residul (selisih antara nilai duga dengan nilai pengamatan sebenarnya) suatu pengamatan ke pengamatan lain antara variabel bebas ikhlas dan spiritualitas kerja.

\section{Uji Hipotesis}

Hasil analisis regresi berganda menunjukkan nilai signifikansi 0,004 ( $\mathrm{p}<0,05)$, artinya dapat disimpulkan bahwa ada pengaruh ikhlas dan spiritualitas kerja terhadap profesionalisme 
guru di pondok pesantren Darul Hijrah Putri Martapura. Untuk lebih jelasnya berikut ini adalah tabel hasil analisis regresi berganda:

\section{Tabel 1}

\begin{tabular}{ccccc}
\hline Model & $\mathrm{R}$ & R Square & Adjusted R Square & Std. Error of the Estimate \\
1 &, $447^{\mathrm{a}}$ &, 199 &, 167 & 4,269 \\
\hline
\end{tabular}

Dari tabel 1 di atas diketahui bahwa nilai koefisien determinan ( $R$ square) sebesar 0.199. Hal tersebut menunjukkan bahwa variabel bebas ikhlas dan spiritualitas kerja secara bersamasama memberi sumbangan efektif terhadap variabel terikat profesionalisme guru sebesar 19,9\%.

Pada penelitian ini juga dilakukan analisis regresi sederhana untuk mengetahui bagianbagian dari analisis berganda. Hasil analisis regresi sederhana untuk pengaruh variabel ikhlas terhadap profesionalisme guru menunjukkan nilai signifikansi sebesar 0,023 ( $p<0,05)$, artinya ada pengaruh ikhlas terhadap profesionalisme guru di pondok pesantren Darul Hijrah Putri Martapura. Untuk lebih jelasnya berikut ini tabel hasil analisis regresi sederhana ikhlas terhadap profesionalisme guru:

Tabel 2

\begin{tabular}{ccccc}
\hline Model & $\mathrm{R}$ & R Square & Adjusted R Square & Std. Error of the Estimate \\
\hline 1 &, $437^{\mathrm{a}}$ &, 191 &, 156 & 4,431 \\
\hline
\end{tabular}

Dari tabel 2 di atas diketahui bahwa nilai koefisien determinan ( $R$ square) sebesar 0,191. Hal tersebut menunjukkan bahwa variabel bebas ikhlas memberi sumbangan efektif terhadap variabel terikat profesionalisme guru sebesar 19,1\%.

Selanjutnya hasil analisis regresi sederhana untuk pengaruh variabel spiritualitas kerja terhadap profesionalisme guru menunjukkan nilai signifikansi sebesar 0,002 ( $<<0,05)$, artinya ada pengaruh spiritualitas kerja terhadap profesionalisme guru di pondok pesantren Darul Hijrah Putri Martapura. Untuk lebih jelasnya berikut ini adalah tabel hasil analisis regresi sederhana spiritualitas kerja terhadap profesionalisme guru: 
Tabel 3

\begin{tabular}{ccccc}
\hline Model & $\mathrm{R}$ & $\mathrm{R}$ Square & Adjusted R Square & Std. Error of the Estimate \\
\hline 1 &, $410^{\mathrm{a}}$ &, 168 &, 152 & 4,308
\end{tabular}

Dari tabel 3 di atas diketahui bahwa nilai koefisien determinan ( $R$ square) sebesar 0,168. Hal tersebut menunjukkan bahwa variabel bebas spiritualitas kerja memberi sumbangan efektif terhadap variabel terikat profesionalisme guru sebesar $16,8 \%$.

Penelitian ini juga membuat kategorisasi untuk setiap variabel, hal ini bertujuan untuk menempatkan individu atau subjek penelitian ke dalam kelompok-kelompok yang posisi berjenjang menurut suatu kontinum berdasarkan atribut yang diukur (Azwar, 2013). Berikut data tabel yang akan menjabarkan tentang tingkat ikhlas, spiritualitas kerja, dan profesionalisme guru di pondok pesantren Darul Hijrah Putri Martapura.

Tabel 4

Tingkat Ikhlas pada Guru

\begin{tabular}{cccc}
\hline Kategori & Norma & Frekuensi & Persentase \\
\hline $\mathrm{X}>37,33$ & Tinggi & 6 & $11,3 \%$ \\
$30,67 \leq \mathrm{X}<37,33$ & Sedang & 28 & $52,8 \%$ \\
$\mathrm{X}<30,67$ & Rendah & 12 & $22,6 \%$ \\
\hline
\end{tabular}

Berdasarkan tabel 4 di atas dapat diketahui bahwa tingkat ikhlas guru di pondok pesantren Darul Hijrah Putri Martapura dengan kategori tinggi sebesar 11,3\% (6 orang), kategori sedang 52,8\% (28 orang) dan pada kategori rendah 22,6\% (12 orang).

\section{Tabel 5}

Tingkat Spiritualitas Kerja

\begin{tabular}{cccc}
\hline Kategori & Norma & Frekuensi & Persentase \\
\hline$X>55,33$ & Tinggi & 20 & $37,7 \%$ \\
$48,67 \leq X<55,33$ & Sedang & 22 & $41,5 \%$ \\
$X<48,67$ & Rendah & 2 & $3,8 \%$ \\
\hline
\end{tabular}


Berdasarkan tabel 5 di atas dapat diketahui bahwa tingkat spiritualitas kerja guru di pondok pesantren Darul Hijrah Putri Martapura dengan kategori tinggi sebesar 37,7\% (20 orang), kategori sedang 41,5\% (22 orang), dan pada kategori rendah 3,8\% (2 orang).

\section{Tabel 6}

Tingkat Profesionalisme Guru

\begin{tabular}{cccc}
\hline Kategori & Norma & Frekuensi & Persentase \\
\hline$X>51$ & Tinggi & 6 & $11,3 \%$ \\
$43 \leq X<51$ & Sedang & 28 & $52,8 \%$ \\
$X<43$ & Rendah & 19 & $35,8 \%$
\end{tabular}

Berdasarkan tabel 6 di atas dapat diketahui bahwa tingkat profesionalisme guru di pondok pesantren Darul Hijrah Putri Martapura dengan kategori tinggi sebesar 11,3\% (6 orang), kategori sedang 52,8\% (28 orang) dan pada kategori rendah 35,8\% (19 orang).

\section{Pembahasan}

Mulyasa mendefinisikan profesionalisme guru sebagai perpaduan antara kemampuan personal, keilmuan, teknologi, sosial dan spiritual yang secara kaffah membentuk kompetensi standar profesi guru, yang mencangkup penguasaan materi, pemahaman peserta didik, pembelajaran yang mendidik, pengembangan pribadi dan profesionalisme (H.E. Mulyasa, 2013). Guru merupakan profesi profesional dimana dituntut untuk berupaya semaksimal mungkin menjalankan profesinya sebaik mungkin. Guru membutuhkan jabatan atau profesi yang memerlukan keahlian khusus. Pekerjaan ini tidak dapat dilakukan oleh orang yang tidak memiliki keahlian untuk melakukan kegiatan atau pekerjaan sebagai seorang guru, keahlian sebagai guru profesional harus menguasai seluk beluk pendidikan dan pengajaran dengan bebagai ilmu pengetahuan lainnya yang perlu dibina dan dikembangkan melalui masa pendidikan tertentu (Listiyani, 2014). Jadi, profesionalisme guru merupakan kemampuan melaksanakan sesuatu yang diperoleh melalui pendidikan, menunjuk pada performance dan perubahan yang rasional untuk memenuhi spesifikasi tertentu dalam melaksanakan tugastugas pendidikan. Gambaran profesionalisme ditinjau melalui aspek yang dikemukakan oleh 
Mulyasa yaitu kompetensi pedagogik, kompetensi kepribadian, kompetensi sosial dan kompetensi profesional.

Faktor yang memiliki pengaruh terhadap profesionalisme guru diantaranya adalah ikhlas dan spiritualitas kerja. Ikhlas menurut Chizanah dan Hadjam adalah sebuah ketulusan dalam menjalankan segala hal dan memberikan pertolongan, kerelaan dan penerimaan (Muniroh, 2016). Sedangkan spiritualitas kerja menurut Milliman, Czaplewski, dan Ferguson juga mengemukakan bahwa spiritualitas kerja adalah mengungkapkan keinginan untuk menemukan arti dan tujuan dalam hidup, serta merupakan proses mewujudkan rangkaian nilai-nilai individu yang dimiliki seseorang (Mengko \& Vesty Like Sambeka, 2018).

Gambaran ikhlas melalui aspek-aspek yang dikemukakan oleh Chizanah dan Hadjam. Aspek-aspek itu dimuat dalam skala sesuai dengan teori yang sudah dijelaskan oleh peneliti dalam definisi operasional dan landasan teori dimana aspek-aspek tersebut berkaitan dengan perilaku yang menggambarkan ikhlas seseorang seperti motif transendental, pengendalian emosi, tidak adanya superiority feeling, dan konsepsi sebagai hamba Tuhan. Sedangkan gambaran spiritualitas kerja ditinjau melalui aspek-aspek yang dikemukakan oleh Milliman, Czaplewski, dan Ferguson. Dimana aspek-aspek itu berkaitan dengan perilaku yang menggambarkan spiritualitas kerja seperti pekerjaan yang bermakna (meaningful work), rasa komunitas (sense of community), dan penegakan nilai dalam organisasi (alignment with organizational value).

Pada penelitian ini, peneliti mengajukan tiga hipotesis kerja (Ha) dan ketiga hipotesis kerja tersebut dapat diterima. Berdasarkan hasil uji hipotesis pertama dan untuk menjawab rumusan masalah kesatu, diketahui dengan jelas bahwa terdapat pengaruh yang signifikan antara ikhlas dan spiritualitas kerja terhadap profesionalisme guru di pondok pesantren Darul Hijrah Putri Martapura, dengan sumbangan efektif yang diberikan sebesar 19,9\% sedangkan 80,1\% dipengaruhi oleh faktor lain faktor lain yang tidak termasuk dalam penelitian ini.

Berdasarkan hasil uji hipotesis kedua dan untuk menjawab rumusan masalah tersebut, diperoleh pengaruh yang signifikan antara ikhlas terhadap profesionalisme guru di pondok pesantren Darul Hijrah Putri Martapura, memiliki sumbangan efektif 19,1\%. Kemudian berdasarkan hasil uji hipotesis ketiga dan untuk menjawab rumusan masalah ini, diperoleh 
hasil bahwa terdapat pengaruh yang signifikan antara spiritualitas kerja terhadap profesionalisme guru di pondok pesantren Darul Hijrah Putri Martapura dengan memberikan pengaruhnya sebesar $16,8 \%$.

Sesuai dengan hasil analisis, maka dapat diambil kesimpulan bahwa terdapat pengaruh yang signifikan antara ikhlas dan spiritualitas kerja terhadap profesionalisme guru pondok pesantren Darul Hijrah Putri Martapura. Hal ini menyatakan bahwa profesionalisme guru seseorang tidak mutlak dipengaruhi oleh ikhlas dan spiritualitas kerja yang dimiliki oleh individu. Antara ikhlas dan spiritualitas kerja memang dapat memberikan pengaruh terhadap profesionalisme guru, akan tetapi bisa saja seseorang yang memiliki profesionalisme guru yang tinggi dikarenakan faktor-faktor penyebab lain yang tidak diteliti pada penelitian ini. Hal ini juga dibuktikan pada penelitian yang dilakukan oleh Tutik Yuliani dengan judul "Faktor-faktor yang mempengaruhi Profesionalisme Guru MTs Negeri Di Balikpapan Timur" . Pada penelitian ini disebutkan faktor-faktor yang mempengaruhi profesionalisme guru adalah iklim organisasi, kompetensi guru, dan sikap (Tutik Yuliani, 2016).

Untuk menjawab rumusan masalah yang keempat tentang tingkat ikhlas pada guru pondok pesantren di Darul Hijrah Putri Martapura, diketahui dari hasil penelitian ini bahwa ikhlas berada pada kategori tinggi sejumlah tinggi sebanyak 6 orang atau sebesar 11,3\%, dan kategori sedang sebanyak 28 orang atau sebesar 52,8\% dan kategori rendah sebanyak 12 orang guru atau sebesar 22,6\%. Secara umum ikhlas guru pondok pesantren Darul Hijrah Putri Martapura berada pada kategori sedang. Ikhlas pada tingkat sedang ini juga bisa dikatakan dalam keadaan baik. Pada dasarnya setiap ikhlas seseorang itu berbeda, adapun faktor yang dapat mempengaruhi ikhlas seseorang adalah tidak terpaksa, bersungguh-sungguh, semangat, sabar, tanggung jawab, tidak mengharap pujian, tidak mengharap imbalan, tidak mempunyai kepentingan tertentu dan tidak mengharap gaji (Ummi Inayati, 2018).

Sifat ikhlas yang baik akan memberikan dampak yang baik pula pada individunya. Menurut Qalami dalam Chizanah, ikhlas sebagai hasrat yang murni hanya berharap mendapat restu Tuhan ketika melaksanakan suatu tindakan, dan bukan menyekutukan Tuhan dengan yang lain. Ikhlas bagaikan wujud sikap membantu didasari hasrat baik, tidak mementingkan diri sendiri, dan keberkahan bagi dirinya (Chizanah, 2011). 
Ikhlas adalah satu-satunya tugas dan kewajiban manusia kepada Allah SWT. Artinya, seluruh aktivitas hidup dan kehidupan manusia (gerak dan diamnya) yaitu dalam rangka pengabdian dan perilaku yang jauh dari menyekutukan Allah SWT. Ikhlas juga menjadikan perbuatan semata-mata hanya untuk mendapat ridha Allah SWT, bukan untuk meraih pamrih duniawi, dengan tidak mengharapkan pujian dari manusia dan senantiasa menjaga niatnya dengan benar (Muniroh, 2016).

Pada penelitian ini ikhlas berada pada tingkat sedang atau baik juga diimbangi dengan spiritualitas kerja yang umumnya pada tingkat sedang. Dari hasil penelitian ini diperoleh data bahwa spiritualitas kerja berada pada kategori tinggi sejumlah 20 orang atau sebesar 37,7\%, dan kategori sedang sebanyak 22 orang atau sebesar 41,5\% dan kategori rendah sebanyak 2 orang atau sebesar 3,8\%. Individu yang memiliki tingkat spiritualitas kerja yang baik akan memberikan manfaat yang besar bagi kehidupan seseorang, seperti peningkatan kualitas hidup sehingga dapat merasakan kesuksesan dan kesejahteraan dalam hidup.

Spiritualitas kerja menjadikan seseorang mampu meningkatkan kesejahteraan dan kualitas hidup individu, mampu memberikan rasa tujuan makna di tempat kerja, dan memberikan kepada individu rasa keterhubungan dan rasa komunitas. Spiritualitas dalam pekerjaan akan menghasilkan hal-hal positif bagi individu dan organisasi. Meintegrasikan spiritualitas di tempat kerja, akan membuat individu merasakan makna dan perasaan bertujuan dalam kehidupannya. Spiritualitas dapat membuat individu lebih efektif dalam bekerja, karena individu yang melihat pekerjaan mereka sebagai alat untuk meningkatkan spiritualitas akan menunjukkan usaha yang lebih besar dibanding individu yang melihat pekerjaannya hanya sebagai alat untuk memperoleh uang (Nurtjahjanti, 2010).

Selanjutnya untuk menjawab rumusan masalah yang terakhir atau yang keenam tentang tingkat profesionalisme pada guru di pondok pesantren Darul Hijrah Putri Martapura. Dari hasil penelitian ini diperoleh data bahwa kategori tinggi sebanyak 6 orang atau sebesar 11,3\%, dan kategori sedang sebanyak 28 orang atau sebesar 52,8\% dan kategori rendah sebanyak 19 orang atau sebesar 35,8\%. Jadi secara umum profesionalisme guru pada pondok pesantren Datul Hijrah Putri Martapura adalah sedang. Kategori pada tingkatan sedang artinya bisa dikatakan telah dalam kondisi yang baik, tetapi akan lebih baik jika lebih ditingkatkan lagi. 
Karena profesionalisme guru penting dalam meningkatkan kualitas pendidikan, dengan perbaikan kualitas pendidikan dan peningkatan prestasi belajar, maka diharapkan tujuan pendidikan nasional akan terwujud dengan baik. Dengan demikian, keberadaan guru profesional selain untuk mempengaruhi proses belajar mengajar, guru profesional juga diharapkan mampu memberikan mutu pendidikan yang baik sehingga menghasilkan peserta didik yang berprestasi.

\section{Kesimpulan}

Dari hasil analisis data dalam penelitian mengenai pengaruh ikhlas dan spiritualitas kerja terhadap profesionalisme guru pondok pesantren Darul Hijrah Putri Martapura, maka dapat disimpulkan bahwa ada pengaruh yang signifikan antara ikhlas dan spiritualitas kerja terhadap profesionalisme guru. Pengaruh yang diberikan sebesar 19,9\%. Selanjutnya ada pengaruh yang signifikan antara ikhlas dengan profesionalisme guru pada penelitian ini, sebesar 19,1\%. Serta ada pengaruh yang signifikan antara spiritualitas kerja terhadap profesionalisme guru, dengan persentase sebesar 16,8\%. Yang artinya ikhlas dan spiritualitas kerja dapat mempengaruhi profesionalisme guru pondok pesantren Darul Hijrah Putri Martapura. baik secara bersamasama ataupun secara satu persatu. Untuk hasil data ikhlas pada guru di pondok pesantren Darul Hijrah Putri Martapura, dikatakan bahwa pada kategori tinggi berjumlah 6 orang (11,3\%), pada kategori sedang berjumlah 28 orang (52,8\%), dan pada kategori rendah berjumlah 12 orang (22,6\%). Hal ini menunjukkan bahwa ikhlas pada guru pondok pesantren Darul Hijrah Putri Martapura berada pada kategori sedang. Untuk hasil data spiritualitas kerja pada guru pondok pesantren Darul Hijrah Putri Martapura diketahui bahwa pada kategori tinggi berjumlah 20 orang $(37,7 \%)$, dan kategori sedang sebanyak 22 orang (41,5\%) dan kategori rendah sebanyak 2 orang (3,8\%). Hal ini menunjukkan bahwa spiritualitas kerja pada guru pondok pesantren Darul Hijrah Putri Martapura berada pada kategori sedang. Serta untuk hasil data profesionalisme guru pada guru pondok pesantren Darul Hijrah Putri Martapura pada kategori tinggi berjumlah 6 orang guru (11,3\%), dan kategori sedang sebanyak 28 orang guru $(52,8 \%)$ dan kategori rendah sebanyak 19 orang guru $(35,8 \%)$. Hal ini menunjukkan bahwa 
profesionalisme guru pada guru pondok pesantren Darul Hijrah Putri berada pada kategori sedang.

\section{Saran}

Penelitian ini menunjukkan adanya pengaruh ikhlas dan spiritualitas kerja terhadap profesionalisme guru di pondok pesantren Darul Hijrah Putri Martapura. Untuk itu disarankan kepada pondok pesantren Darul Hijrah Putri Martapura hendaknya berupaya meningkatkan perilaku profesionalisme guru, tidak hanya melalui pengembangan ikhlas dan spiritualitas kerja, namun juga memperhatian faktor-faktor lain yang dapat meningkatkan profesionalisme guru. Karena profesionalisme guru akan memberikan dampak positif bagi pondok pesantren itu sendiri. Untuk Peneliti selanjutnya yang menggunakan variabel yang sama disarankan agar menggunakan teori-teori yang berbeda untuk memperkaya pembahasan penelitian terkait variabel ikhlas, spiritualitas kerja, dan profesionalisme guru. Selain itu peneliti juga menyarankan untuk penelitian selanjutnya meneliti lebih mendalam mengenai variabelvariabel yang dapat mempengaruhi profesionalisme guru. penelitian selanjutnya juga bisa mengubah metode penelitian ke penelitian kualitatif agar mendapatkan uraian data penelitian yang lebih mendalam mengenai faktor yang dapat mempengaruhi profesionalisme guru.

\section{Referensi}

Alexandri, M. B., \& Fithriya Zahra. (2017). Hubungan Industrial: Perbandingan Spiritualitas Di Tempat Kerja Dan Efektifitas Organisasi Antara India dengan Indonesia. Jurnal AdBispreneur, 2(2).

Azwar, S. (2013). Penyusunan Skala Psikologi. Yogyakarta: Pustaka Pelajar.

Chizanah, L. (2011). ikhlas=prososial? dalam Jurnal Psikologi Islam (JPI) Lembaga Penelitian Pengembangan Psikologi dan Keislaman (LP3K), 8(2).

Chizanah, L., \& Hadjam, M. N. R. (2013). Penyusunan Instrumen Pengukuran Ikhlas. Jurnal Psikologika, 18(1).

Daud, M. R. H. (2017). Ikhlas Dalam Perspektif Al Qur'an. Skripsi, Universitas Islam Negeri ArRanirydarussalam, Banda Aceh.

Depdikbud. (2005). Kamus Besar Bahasa Indonesia. Jakarta: Balai Pustaka.

Endang Mulyatiningsih. (2011). Riset Terapan Bidang Pendidikan dan Teknik. Yogyakarta: UNY Press,.

Faturahman, P., \& Suryana, A. (2012). Guru Profesional. Bandung: Rafika Aditama. H.E. Mulyasa. (2013). Standar Kompetensi dan Sertifikasi Guru. Bandung: Remajaja Rosdakarya. 
Listiyani. (2014). Kontribusi Pelatihan dan Pengalaman Mengajar Terhadap Profesionalisme Guru Sekolah Dasar Negeri di Kecamatan Gunungkidul. Universitas Negeri Yogyakarta, Yogyakarta.

Manurung, T. M. S., \& Harni, B. (2008). Kajian Motivasi Kerja dan Produktivitas Karyawan. Jurnal Ilmiah Ranggagading (JIR), 8(2), 103-114.

Mengko, S. M. H., \& Vesty Like Sambeka. (2018). Pengaruh Spiritualitas Kerja Terhadap Kepuasan Kerja Dosen Politeknik Negeri Manado. Jurnal Akuntabilitas Manajemen Pendidikan, 6(1).

Muniroh, S. (2016). Korelasi ikhlas Dengan Etos Kerja Guru PAI Honorer Tingkat SD Se Kecamatan Buayan Kabupaten Kebumen (Skripsi). Fakultas Ilmu Tarbiyah dan Keguruan, Yogyakarta.

Nurtjahjanti, H. (2010). Spiritualitas Kerja Sebagai Ekspresi Keinginan Diri Karyawan Untuk Mencari Makna dan Tujuan Hidup dalam Organisasi. 7(1), 27.

Sriani, N., Srigati, Mushofiah, S., \& Imam Maliki. (2016). Membangkitkan Prestasi Belajar Matematika Siswa Sekolah Dasar Melalui Media Sudut Siku-siku. Jurnal Riset dan Konseptual, 1(1).

Sugiyono. (2010). Metode Penelitian Pendidikan (Pendekatan Kuantitatif, Kualitatif, dan RED). Bandung: Alfabeta.

Sujarweni, V. W. (2019). SPSS Untuk Penelitian. Yogyakarta: Pustaka Baru Press.

Syamsuddin. (2012). Memahami Dimensi Spiritualitas Dalam Praktek Pekerjaan Sosial. 17(2).

Tutik Yuliani. (2016). Faktor-faktor yang Mempengaruhi Profesionalisme Guru MTs Negeri Balikpapan Timur. E-Jurnal.

Ulfah, C., Yuliejantiningsih, Y., \& Soegeng. (2017). Pengaruh Kompensasi dan Motivasi Kerja Terhadap Profesionalisme Guru Paud di Kecamatan Ungaran Barat Kabupaten Semarang. Jurnal Manajemen Pendidikan, 5(1).

Ummi Inayati. (2018). Implementasi Keikhlasan dan Kedisiplinan dalam Meningkatkan Kinerja Guru (Studi Multisitus di MIN Muntafa'ul Ulum Bojonegoro. Universitas Islam Negeri Maulana Malik Ibrahim Malang, Malang.

Wahyuning, T. (2016). Pengaruh Budaya Organisasi, komitmen, motivasi Berprestasi Terhadap Profesionalisme Guru SD Negeri Kecamatan Abung Tinggi Kabupaten Lampung Utara. Universitas Lampung, Lampung.

Widyaningsih. (2016). Pembaharuan Manajemen Pendidikan Pondok Pesantren: Studi Analisis Manajemen Pesantren Oleh KH. Abdullah Syukri Zarkasyi. STAIN Curup, Curup.

Wulandari, K. (2017). Pengaruh Spiritualitas Di Tempat Kerja, Kepemimpinan Spiritual Dan Kelebihan Beban Kerja Pada Kepuasan Kerja. Skripsi, Semarang.

Yogatama, L. A. M. (2015). Kajian Spiritualitas di Tempat Kerja pada Konteks Organisasi Bisnis. 42(1), 3. 


\begin{tabular}{|l|l|l|l|l|}
\hline Submit & Review & Revisi & Diterima & Publis \\
\hline $14-12-2020$ & - & - & $03-02-2021$ & $22-04-2021$ \\
\hline
\end{tabular}

\section{Gisya}

\section{Progran Studi Psikologi Islam}

Fakultas Ushuluddin dan Humaniora

Universitas Islam Negeri Antasari Banjarmasin

Email : ginagisya23091998@gmail.com 